\title{
Family, School and Educators: Important Pillars in the Perception of Childhood Depression
}

\author{
Luã T. G. Câmara, Paulo R. S. Stephens \\ Instituto Oswaldo Cruz-Fiocruz, Postgraduate in Teaching in Biosciences and Health, Laboratory of Innovations in Therapies, \\ Teaching and Bioproducts, Rio de Janeiro, Brazil \\ Email: luateixeira10@gmail.com,paulor2000@yahoo.com.br
}

How to cite this paper: Câmara, L. T. G., \& Stephens, P. R. S. (2021). Family, School and Educators: Important Pillars in the Perception of Childhood Depression. Creative Education, 12, 2715-2732. https://doi.org/10.4236/ce.2021.1211201

Received: August 25, 2021

Accepted: November 27, 2021

Published: November 30, 2021

Copyright $\odot 2021$ by author(s) and Scientific Research Publishing Inc. This work is licensed under the Creative Commons Attribution International License (CC BY 4.0).

http://creativecommons.org/licenses/by/4.0/

Open Access

\begin{abstract}
Currently, mental health professionals say that there is no doubt about the existence of depression in children, who can even be affected at preschool age. Therefore, the perception of the family, school and educators is important to assist in early diagnosis, as well as in treatment. This article aims to carry out a literature review on depression in children, seeking statistical data published in Brazil, between 1995 and 2018, a period of 23 years. Scientific articles were investigated through the databases, Scielo, PubMed, PePSIC and Academic Google, resulting in 18 articles found. It is concluded that there is little research on the subject in Brazil, emphasizing the importance of the perception of the family, school and educators.
\end{abstract}

\section{Keywords}

Childhood Depression, Family, School, Educators

\section{Introduction}

Currently, childhood depression prevails in the list of Public Health concerns, as reported by the World Health Organization (WHO), reporting that in the last ten years, the number of diagnoses of children aged 6 to 12 years has increased significantly from $4.5 \%$ to $8 \%$, out of those who are not diagnosed. WHO mentions that by the end of 2020, depression will become the most disabling illness in the world (World Health Organization, 2002).

This psychopathology, according to Dr. Jeffrey A. Miller in his book The Reference Book for Childhood Depression, is a mood disorder, which expresses itself through a set of symptoms, such as affective exacerbation (sadness), alteration in mental processing and significantly interfering with behavior, for exam- 
ple hypobulia or abulia. The development of depressive disorders usually stems from two points such as: genetic predisposition and/or triggered triggers, such as social problems, involving separation from legal guardians, bullying, physical and psychological negligence, leading to harmful psycho-behavioral responses, such as aggression, unruly problems, hyperactivity, obesity or weight loss, as well as domestic violence and sexual abuse (Miller, 2003).

The damages to the health of children who face these types of violence are diverse, since we are biopsychosocial beings, from serious mental illnesses, chemical addictions to metabolic diseases.

As stated in the Diagnostic and Statistical Manual of Mental Disorders (DSM-V, 2014), depression includes several levels, with a set of symptoms and what differs between them are the aspects of duration, timing and etiology. With this, this disorder is not called "freshness", "trickery" or as erroneously in common sense it is adjective as "lazy" the children and adolescents who are affected. Depression, specifically in childhood, is usually underestimated and neglected by family members, educators, schools and seen as just "trick" and/or "bad manners” (Kupfer \& Regier, 2014).

Although many people are still unaware of childhood depression or do not believe it, it does not cease to exist and serious studies have been warning us about this disease in childhood. To change this obscure scenario, measures are needed, for example, dissemination, communication between the mental health area and the educational area, in order to root out childhood depression from invisibility, that is, to make knowledge clearly relevant about this psychopathology, in order to provide the minimization of possible incidents in the future (Miller, 2003).

According to Dr. Ana Kleinman, child psychiatrist and researcher at the Bipolar Disorder Program at the Institute of Psychiatry of the Hospital das Clínicas in São Paulo, she points out that approximately $2 \%$ of preschool and school-age children suffer from depressive disorder and the statistical number grows to $11.7 \%$ when they enter the puberty stage (In Estação Saúde-Educação e Cultura Ltda.).

Therefore, it is important to emphasize that this psychopathology brings remarkable impairments with regard to social, cognitive and emotional functions, affecting not only the child's development, but also the family and school relationship. It's fundamental that a social and school reorganization changes in values in the sense of giving new meaning to life, in order to help and minimize the sufferings experienced by children (Miller, 2003).

From the moment we understand that we are biopsychosocial beings, that is, we are influenced by biological, psychological and social factors, it is understood that the pubic child can also have depressive factors, whether by genetic predisposition or negative life experiences. Many scholars in the field of neuroscience, medicine, behavioral psychology and education point out that depressive states in children are occurring at an ever earlier age and despite epidemiological data 
showing that there are currently no uncertainties such as episodes of depression in childhood (White, 1989; Bandim \& Cols, 1995; Andriola \& Cavalcante, 1999; Baptista \& Golfeto, 2000; Barbosa \& Gaião, 2001; Hallak, 2001 in Cruvinel \& Boruchovitch, 2003).

In view of this, the individual to be diagnosed with depression must have three essential pillars, which are: intensity, persistence and behavioral changes. Therefore, 15-year-olds do not commit suicide out of the blue, and after investigating the history for such action, depression is concluded, showing and justifying that this psychopathology does not arise, but it has already been following it and strengthening it since an early age (Kandel, Schwartz, Jessell, Siegelbaum, \& Hudspeth, 2014).

The depressive disorder affects at any age, but the chances of increase and complications are in the puberty phase, that is, in the transition from childhood to adolescence. A study by Kashani and Sherman investigated and surveyed increasing incidence rates of depressive disorders: $0.9 \%$ in preschool-age children, $1.9 \%$ in school-age children, and $4.7 \%$ in adolescents causing an increase in illness and disability around the world (Duailibi \& Silva, 2013).

In 1989, Fleming's group led a survey of 2852 children, aged 6 to 16 years, based on the DSM-III, there was a prevalence of depressive symptoms with $0.6 \%$ in children and $1.8 \%$ in adolescents (Fleming, Offord, \& Boyle, 1989). In 1994, researchers investigated 792 students, applying the "Children's Depression Inventory (CDI)" and the sample reported $8.3 \%$ of the total with moderate depression (Chartier \& Lassen, 1994).

According to the DSM-V (Diagnostic and Statistical Manual of Mental Disorders), the common feature of depressive disorder is the presence of sad mood, feeling of emptiness, high irritability, insomnia, decreased libido, accompanied by somatic and cognitive changes that directly interfere with the individual's ability to function (Kupfer \& Regier, 2014).

Therefore, it is important to understand this disorder to demystify depression in children, minimize prejudices, provide a more concrete dissemination, with relevant data, sensitizing the community not only in Brazil, but throughout the world and thus, providing a contribution to the diagnosis and early intervention, aiming to bring the family, school and educators into the process, in order to welcome and provide the necessary support for this child who is presenting a picture of depression.

\section{Statistical Data on Child Depression in Brazil}

Despite the denial of depression in young people and children since the beginning of the 20th century (MILLER in Carmo et al., 2009), series researches show over the years, increasing incidences of depression in children and adolescents, due to various factors. And currently, there are still complex obstacles for the children's tutors, educators and school, in identifying the symptoms and behavioral signs, seriously aggravating the scenario, usually, putting the problem 
aside, the individual starts to receive no assistance, guidance on the what is happening and/or erroneously being labeled with pejorative nomenclatures, making the situation worse (Vieira, Estanislau, Bressan, \& Bordin, 2014).

There are behaviors that are identified with the age group affected by this psychopathology, such as anxiety, phobias, irritability with easy crying, sleep disorders, decreased or increased appetite, somatic pain, sadness, boredom, and in addition to poor school performance, which it is one of the main problems of depression at this age, causing social isolation, refusal to go to school, among others (Bahls, 2004).

Currently, in Brazil, epidemiological data and studies focused on childhood depression are still scarce, although the research that already exists, reveals relevant data when confronted with rates of children in other countries. With this, some researches carried out in Brazil were gathered, placed below in chronological order related to rates of children affected by this psychopathology, from 1995 to 2018.

Starting in 1995, José M. Bandim; Everton B. Sougey and Tárcio FR de Carvalho, evaluated 32 children in Recife, discharged from an outpatient clinic, that is, out of the outpatient setting, aged 6 to 14 years old and who met the DSM-III-R criteria for Depressive Disorder Major (DM), Dysthymic Disorder (DD) and adjustment disorder with Depressed Mood (DAHD). Respectively, the number of diagnoses was: $12.5 \%$ (DM), 68.75\% (DD) and 18.75\% (DAHD) of the total number of children. And in this same study, the highest percentage of children with mood swings was male and aged between 11 and 14 years (Bandim, Sougey, \& Carvalho, 1995).

In 1999, the research by Wagner B. Andriola and Cavalcante L. Rodrigues evaluated 345 preschool students, aged 5 and 6 years, both genders, using the Depressive Symptomatology Scale for Teachers (ESDM-FOR). With the responses collected from preschool teachers taken from the ESDM-P, they reported that $3.9 \%$ of the students had symptoms suggestive of depression (Andriola \& Rodrigues, 1999). In 2000, Baptista and Golfeto, reported the encounter of $1.48 \%$ students, from 7 to 14 years old, in a private school in Ribeirão Preto-SP, being evaluated with the CDI and highlighting if the occurrence in female children (Baptista and Golfet in Cruvinel and Boruchovitch, 2003).

Another research carried out by Hallak, in 2001, in a public school in Ribeirão Preto-SP, analyzed 602 students, between 7 and 12 years old. Using the Child Depression Inventory (CDI), it highlighted about $6 \%$ of incidence of depressive disorder and when used the Depressive Symptomatology Scale for Masters (ESDM), it showed about 3\% (Hallak, 2001 in Cruvinel \& Boruchovitch, 2003). In the same year, Barbosa and Gaião analyzed 807 children aged 7 to 17 years in the interior of Paraiba, using the CDI as an instrument, which revealed $22 \%$ of students with depressive symptoms in their analysis. the ages of 13 and 14 years. The same researchers evaluated 344 children between 11 and 13 years old, with the aim of analyzing the psychometric aspects of the CDRS-R scale, showing $0.9 \%$ with major depression and 3.2\% with dysthymia (Barbosa \& Gaião, 2001 in Cruvinel 
\& Boruchovitch, 2003).

In the city of Curitiba, a survey carried out by Saint-Calir Bahls, in 2002, found $20.3 \%$ of 463 students, aged between 10 and 17 years old, exceeding the cutoff point of 19 of the Child Depression Inventory (Children's Depression Inventory-CDI), showing the symptoms of depression present in these students (Bahls, 2002).

In 2003, in the city of Campinas-SP, a survey carried out by Cruvinel in a public school reported the existence of depressive symptoms in 3.55\% of 169 children in Elementary School I ( $3^{\text {rd }}, 4^{\text {th }}$ and $5^{\text {th }}$ grade), of both sexes. The result according to research, although not alarming, shows that children are also affected by this psychopathology (Cruvinel, 2003).

In the state of Minas Gerais, a 2005 survey by Fonseca, Ferreira and Fonseca showed a score above 17 on the Child Depression Inventory (CDI), in $13.7 \%$ of 519 students aged between 7 and 13 years old. presenting depressive symptoms (Fonseca, Ferreira, \& Fonseca, 2005). In the same year, in 2005, the researchers, Cruvinel and Boruchovitch, analyzed a group of children in the city of Campinas, using the original inventory (Children's Depression Inventory), involving 157 students, found 17\% (Cruvinel \& Boruchovitch, 2008).

In 2006, in the city of Uberaba-MG, 791 students from a private school were evaluated, applying the Self Reporting Questionnaire (SRQ-20), an instrument developed by the World Health Organization (WHO) containing 20 questions. The survey showed the presence of depressive symptoms in $45.5 \%$, predominantly in females (Rocha, Ribeiro, Pereira, Aveiro, \& Silva, 2006). In 2009, a study carried out with 42 students in the city of Ituverava-SP, answered the Child Depression Inventory (CDI) and revealed $48 \%$ of students with depressive symptoms (Carmo et al., 2009).

In 2011, the research by Golfeto, D.Oliveira, Baptista and Bisson covered a greater number of places, containing Ribeirão Preto and 6 cities in the region, managing to analyze 5,974 students, between 6 and 18 years of age, using as an instrument, the Child Depression Inventory (CDI). It predominated in Ribeirão Preto with $6.10 \%$, Franca with $4.90 \%$, Sertãozinho with $9.60 \%$, Descalvado with $5.12 \%$, Batatais with $4.50 \%$, Cravinhos and Brodowski with the highest prevalence, respectively with $8,15 \%$ and $8.17 \%$. With this, the research found a higher incidence among female students. The relevance of this study was highlighted in relation to the age context, with a higher prevalence in children aged 6 and 13 years (Golfeto, Oliveira, Baptista, \& Bisson, 2011).

In 2013, Argimon, Terroso, Barbosa, Lopes, published a survey of 88 students aged 12 to 17 who attended the sixth and seventh grades of an elementary school. For this research, they used the "Beck Depression Scale (BDI-II)", which resulted in $26 \%$ of students suggestive of clinical depression (Argimon, Terrosso, Barbosa, \& Lopes; 2013).

The following year, in 2014, Thiengo, Cavalcante and Lorisi conducted a literature review on the prevalence of depressive symptoms and identified a 
significant variation from $0.6 \%$ to $30 \%$ of occurrence of the disorder according to its causes (Thiengo, Cavalcante, \& Lorisi, 2014). In 2016, a survey conducted in Salvador, with 220 students aged 11 to 17 years from the public network, found a $7.72 \%$ prevalence of depressive symptoms (Couto, Reis, \& Oliveira, 2016).

In 2017, Baptista evaluated 1697 elementary school students (among the $5^{\text {th }}$ and $9^{\text {th }}$ grades) and high school students ( $1^{\text {st }}$ and $2^{\text {nd }}$ grade) in public schools in Minas Gerais and in the state of São Paulo. The research used the instrument "Batista Depression Scale Children and Youth Version (EBADEP-IJ) and was divided into two groups each containing 708 children aged 8 to 11 years and 1235 adolescents aged 12 to 17 years according to the guidelines of the Statute of the Child and Adolescents (Law No. 8069, 1900). According to the research, suicidal ideation and low self-esteem were found in children with depressive symptoms, loneliness and helplessness, and in adolescents (Baptista, Borges, \& Serpa, 2017).

And finally, in 2018, Borges and Pacheco analyzed 546 students, children and adolescents from public schools in the interior of São Paulo and Porto Alegre. Using four types of instruments such as the Baptista Depression Scale-Children and Youth Version (Baptista, Borges, \& Serpa, 2017); Child and Youth Depression Indicators Assessment Battery (Borges \& Baptista, 2015). Emotional Self-Regulation Scale (Noronha \& Baptista, 2016). Family Support Perception Inventory (Baptista, 2009). The responses obtained were $40.1 \%$ of depressive symptoms present in the students, with mild symptoms being detected in $4.8 \%$ $\left(\mathrm{n}^{\circ}=26\right.$ students), moderate symptoms $20.3 \%$ ( $\mathrm{n}^{\circ}=111$ students), severe symptom in $15 \%\left(\mathrm{n}^{\circ}=86\right.$ students). The participants who did not present depressive symptoms were $22 \%$ ( $n^{\circ} 121$ students) (Borges \& Pacheco, 2018).

\section{Methodology}

For the choice and deployment of a methodology, it is necessary to realize its relevance for the development of a research, which is the axis of a research, relating the ideals with the facts, the inquiries to understand and discover the causes, as well as trace the paths for the construction of knowledge. As described by Minayo (2004), "[...] it is the path and the instruments proper to approach reality $[. .$.$] the method is the process of development of things".$

Therefore, the present work is an integrative literature review, supported by a qualitative approach, with exploratory objectives. The authors, Tatiana Gerhardt and Denise Silveira (2009), describe that qualitative research does not engage with numerical interpretation, but with non-quantitative issues. The exploratory research aims to investigate the ideas and thoughts of authors in the areas of health and education, making a bibliographical survey based on theoretical references such as books, articles, websites and others, thus creating a bridge between the areas. Thus, this review is carried out through the investigation and synthesis of available studies on the central theme. 
In this sense, the research was carried out in six stages: determination of the guiding question and objective; determination of scientific platforms; systematic search for research according to the topic addressed; data collect; discussion of results and presentation of the literature review.

The guiding question was established by the "PICo" method, where "P" corresponds to the participant/problem: children; the "I" to interest: statistical data; and "Co" to the context: childhood depression, conceiving as a guiding question: "What statistical data exist in the literature about depression in children?" (Stern, Jordan, \& Mcarthur, 2014).

To carry out this research, the survey was carried out through a cautious search in scientific platforms such as Scielo, Pubmed, PePSIC and Google Academic. Keywords selected through descriptors such as: "child depression", "psychological assessment" and "child mental health" were used. As an inclusion criterion, studies published between 1995 and 2018, carried out in Brazil, written in Portuguese and/or English, that were related to the topic and the type of research were not a literature review, totaling 18 researches carried out in schoolchildren, in a period of 23 years.

With regard to the ethical aspects of this research, the legitimacy of the information and authorship of the researched articles was preserved, duly citing and referencing, in accordance with the Vancouver standards.

\section{Results and Discussion}

This article found a total of 110 articles. After reading the titles and abstracts, 92 articles were excluded that included bibliographic survey studies, studies that assess the instruments that aim to assess depressive symptoms and studies that address issues other than depression in children.

In this sense, we searched for statistical data published in Brazil about childhood depression, where 18 studies were selected, from 1995 to 2018, in which they address the topic of childhood depression with research carried out in children and young people from public and private schools. Although research is important for understanding depression in children, it is still limited, mainly aimed at the school environment. Therefore, based on what was analyzed, we can verify that among the total number of children and young people analyzed (total: 12,724 individuals), the number of children and young people affected with depressive symptoms was 3807 individuals, a significant number, showing that in this stage of human life, depression is also present, as shown in Chart 1.

However, despite being a not very high percentage, it is worrying, especially with regard to children's mental health. Furthermore, showing the importance of more research aimed at childhood depression. In Brazil, for a while, identified about $17 \%$ of individuals in the general population are affected with depression. A survey conducted in 18 countries revealed a percentage of $11.1 \%$ of people suffering from this mental illness and comparing middle-income countries, Brazil stood out, with 18.4\% (Molina, 2012). 


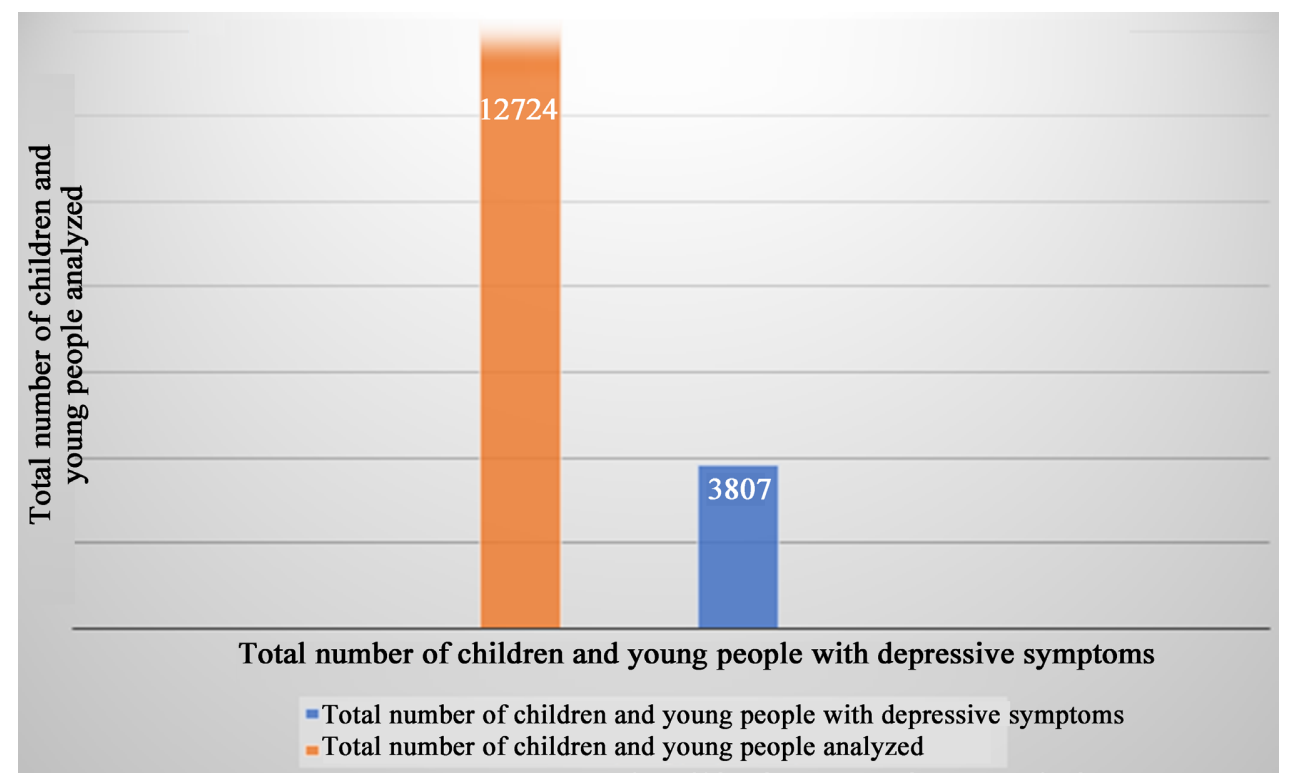

Chart 1. Incidence of depressive symptoms in children and adolescents from the 18 selected survrys.

Although epidemiological data indicate that in contemporary times there is no longer any suspicion about childhood depression, the preponderance of depressive symptoms in children is questionable, since there is an expressive variety in the occurrence rate. This variety, which has been elucidated, due to the methodological differences used and especially because of the difficulty in categorizing the types of depressive disorders and the lack of diagnostic criteria that are equivalent to the collective (Baptista, Baptista, \& DIAS, 2001).

From the study of this very complex topic, which is depression in childhood, statistical data in Brazil was evidenced, where there is a need for more studies and works aimed at children and young people with depression, consequently, the relevance of different views on this theme, in order to help a possible minimization of the child's suffering, as a result a possible improvement in their mental health, as well as in school performance (Cruvinel \& Boruchovitch, 2004).

It is perceived, currently, that there is still a discredit of people about depression in childhood, however, it does not cease to exist and through the bibliographical survey, serious studies were highlighted, contributing with information and warning about depression in the childhood period (Miller, 2003). And as a hypothesis, this work aims to help modify the obscure scenario of lack of information, where we emphasize the importance of promoting mental health in schools, the importance of the educator and the family, not only in the perception of suggestive traits of depression, as well as in childcare, in case they are affected by depression (Vieira, Estanislau, Bressan, \& Bordin, 2014).

Thus, through the compiled studies, it is uncertain to use only a single criterion to elucidate this complex phenomenology that is depression, which can be affected in all age groups and causing several changes in human beings, where this psychopathology encompasses biological and psychological factors and so- 
cial, and these are not distinct, however, they are complementary, that is, they are interconnected (Marconi, 2017).

In summary, the seriousness of the topic and the notoriety of communication between educators, schools, the family, with mental health professionals, the promotion of mental health in the school environment is evident from the data in the scientific literature, (Cruvinel \& Boruchovitch, 2004), as well as, in the prevention of psychopathological disorders, positively promoting the mental health of children, as a harmonious environment, whether at school, at home, as well as a possible improvement in suicide statistics among young people (Oliveira \& Marinho-Araújo, 2010).

In short, studies and research aimed at the mental health of our children, with an emphasis on depression, are relevant, as it provides ways of prevention, awareness of educators, legal guardians, society itself, early detection, evaluation and significant intervention for efficient solutions, as the data obtained from this study shows, depression is proven and we are all vulnerable, including children.

\section{Family, School and Educators, Important Pillars for the Promotion of Mental Health and Awareness about Depressive Disorders}

\subsection{The Family and Its Importance for Prevention}

In the current situation, in society like that of Brazil, the school, educators and the family are inseparable pillars for the development of quality education, benefiting as a return to society. In this way, thinking about education is evoking these three pillars. Starting with the family, which is responsible for elementary education, it is enough to analyze the history of education to see that family transformations directly influence the main transformations in the teaching-learning relationship.

As described by Petzold (1996), the family is the first educational sector and is responsible, essentially, for the way in which the child connects with the world, based on their position in the social structure. Its concept has been undergoing major changes, following developments in economic, cultural, political, technological and currently, the family model is not only patriarchal, but matriarchal or homosexual parents, large, multigenerational families; small; reconstituted, among others (Petzold, 1996; Oliveira \& Marinho-Araújo, 2010). Therefore, due to the plurality of family arrangements, we understand that the family, in relation to the child, is formed by an adult and a child and/or adolescent.

Therefore, for Jean-Jaques Hemery (2008), the family nucleus inaugurates the child's first contact circle, influencing their personality construction (Hemery, 2008 in Carmo et al., 2009). The family can be understood as a segment in the child's psychic development process, which starts from a bond of indifference to individualization. Furthermore, the individual's future emotional responses may be the preeminent emotional reflex of the family (Andolfi, Angelo, Menghi, Nicolo-Corigliano, 1984 in Baptista et al., 2001). 
In view of this, the family has a relevant social role based on social primordialities, such as educating them, instructing and guiding them, so that they have values and behavior in force with the culture in which they live (Bock, Furtado, \& Teixeira, 1999). In Brazil, after the introduction of women into the labor market, which is their right, we have noticed changes in family roles and what calls attention is the high incidence of emotional conflicts in children and adolescents.

As described by Papp (1992: p. 17), the family group is a union of beliefs and values, passed on by the parents, elaborating instructions and rules that help children and adolescents in their biopsychosocial development. Interactions with their family environment reverberate in other social environments, with good positive and negative responses (Minuchin \& Fishiman, 1990).

According to Erik Erikson, child psychoanalyst responsible for the development of the "Theory of Psychosocial Development", reports that certain periods of development are pointed out as vulnerable, in which given influences have a high impact, such as at ages 6 to 12 years, in which there is the so-called evolutionary crisis resulting from the desire for productivity, when the child wants to be socially recognized for his ability to prepare for the adult world (Erikson, 1987). But, we know that the family is not always flexible to provide development, support, direct, correct, particularly in the transition from childhood to adolescence.

And in this sense, today, we see a troubled context with increasing incidences of children and adolescents with emotional problems, for several factors, including: first, the legal guardians are no longer at home because of work or second, they don't there is the presence of a legal guardian to help and direct the child or adolescent or third party, the guardians delegate the responsibility to others. Notably, these influences, without delay, the school structure, the learning process, as more and more children and adolescents arrive with difficulties in various prerequisites that should be worked and encouraged by the family, such as respect, empathy, the right and the wrong, the frustrations, receiving the no, the limits, which help in the fullest psychic development of the being.

As stated by Cória-Sabini, in her book "Development Psychology", parents play an important role in the process of development and autonomy. If they encourage the child's initiatives, praise their success, have certain moments of frustration, they will be contributing to the emergence and strengthening of feelings of self-confidence and self-esteem (Cória-Sabini, 1998).

A survey conducted by Fordham and Indiana Universities, through a validation study of the social support through family scale they created, found a negative connection between family support and depression in children and young people. And according to the survey, this negative relationship has to do with several points, including comfort, emotional support, exchange of information and others (Procidano \& Heller, 1983).

Another study demonstrated that the natural and balanced support of the 
family provides and minimizes the risk of mental problems (Barrera, Sandler, \& Ramsay, 1981). Thus, children and young people who lack social/family support would be likely to develop psychological/psychiatric disorders when faced with conflicting situations (Lovisi, Milanil, Caetano, Abelha, \& Morgado, 1996). In addition, some researchers have reported the difference in influence when comparing a high level of affection versus indifference or rejection and overprotection versus autonomy and independence. For them, the more there is family contact, affection, autonomy and independence, the better the effects will be on the lives of young people and children (Parker, Tupling, \& Brown, 1979).

Therefore, depression in children and adolescents can be related to family support, which contributes to their propensity, fueling different types of problems, such as increasing suicides and the use of narcotics (Birtchnell, 1988; Windle, 1991). In this way, educating, in the etymological sense, expresses to promote, provide the biopsychosocial, physical, intellectual and moral development, referring us to the role of legal guardians and finally, as a consequence of the school (Oliveira \& Marinho-Araújo, 2010).

\subsection{The School and Its Importance for Promotion}

Brazilian epidemiological data are beginning to alert us about the incidence of mental disorders involving children and adolescents, reaching about $10 \%$ to $20 \%$ manifesting some type of mental disorder. According to the Disability Index (Global Burden of Disease), the concussion of psychiatric/psychiatric disorders is ranked as the most harmful of all medical illnesses in the public aged 10 to 24 years (Vieira, Estanislau, Bressan, \& Bordin, 2014). Other data, as described in the report "The health of the Portuguese-Perspective" in 2016, with the children and youth population, is the high consumption of psychotropic substances, becoming worrying, view of this the inconsequential use of "benzodiazepines" and some stimulants that interfere with the Central Nervous System (Albuquerque, 2018).

In Europe, a few years ago, there was a declaration called "European Pact for Mental Health and Well-being" in order to make a European pact involving mental health and well-being, being present in the curricular and extracurricular practices of schools, in addition to awareness of mental health professionals. In some countries, such as Canada, the practice of debating emotions with students, teachers and family members is already included in their school curricula (Vieira, Estanislau, Bressan, \& Bordin, 2014).

In Brazil, which contains a large continental extension, the situation is worrying, as it presents several social and cultural differences. Thus, when the child goes from the family relationship phase to relate to other environments, such as the school, the problem of depression that was previously familiar and individual, now transposes to the school environment, in which it has a fundamental role in helping to identify this psychopathology and helping to suggest it to qualified professionals (Cruvinel \& Boruchovitch, 2004). 
In Brazilian and international scientific literature, in relation to mental health, the school environment stands out as a strategic and particularly benefited niche for the implementation of public (mental) health policies for children and young people, being the axis for promotion and prevention of mental health, providing advances for the protection and minimization of risks related to mental disorders (Vieira, Estanislau, Bressan, \& Bordin, 2014).

The school system has been highlighted, showing the damage caused by mental problems. Some examples of consequences caused by mental disorders in children and adolescents are lower academic performance, school dropout, irritability, aggressiveness, emotional and behavioral problems, among others (Cruvinel \& Boruchovitch, 2003).

In this sense, the school factor, as an environment that centralizes the majority of children and adolescents in the country during the day, in addition to being closer to the population, especially the needy population, than a mental health clinic, which can be provided in partnership with mental health professionals, carrying out early intervention, minimizing discredit and prejudice from family members (Pavoski, Toni, Batista, \& Ignachewski, 2017).

In short, based on the book "Mental Health at School", schools can promote mental health, promoting healthy environments, in which it is positive for the teaching-learning process; develop a health model that involves biopsychosocial aspects; allow more often the cooperation of students; structuring contents involving (mental) health in different areas; promote emotional literacy; granting and valuing the role of teachers in the development of the pedagogical project for health education; enable the qualification of educators (in general); sensitize family members through conversations and organize interconnections with other areas of the health field, among others (Vieira, Estanislau, Bressan, \& Bordin, 2014).

\subsection{Educators and the Importance of Their View}

Currently, it has been noticed that teachers and principals of public schools, mainly, are having a high rate of absence from work, due to students' problems, such as behavioral disorders and concomitantly their health being affected, for various reasons faced by teaching which hinders their work, bringing consequences in various areas (Teixeira, 2018).

Therefore, with the devaluation of the teacher, the lack of public policies in the educational field, of qualifications, the lack of relevant and reliable information, guidelines for appropriate referrals, leads teachers, educators, to continue to have distortions about mental disorders, which consequently ends up subjecting to the medical figure, who in many cases, due to the lack of ethics of the health professional, ends up leading to medicalization. With this, this phenomenon of medicalization in Brazil and abroad, which it triggered in several areas, has as its starting point misinformation (Vieira, Estanislau, Bressan, \& Bordin, 2014). 
Teachers are usually the first to notice something wrong with the child and young person, such as the perception of symptoms of depression, behavioral changes, which present themselves in different ways at school, being one of the first signs is the drop in school performance, as "the decline in performance may be due to poor concentration or lack of interest, typical of a depressive condition" (Bahls, 2004).

The educator (in general) has a remarkable position in the process of awareness and in the importance of his view, as he has experience with several children and young people, enabling a critical look at the behavior of each age group; he observes his students in various environments for a long time, in addition to spending most of the day with his student (Vieira, Estanislau, Bressan, \& Bordin, 2014).

In view of this, the teacher also has a relevant role in participating in providing the student's experiences for diagnosis, since, unlike the legal guardians, it is remarkable that the teacher has more knowledge about the development of children and young people (Carmo et al., 2009). It is noteworthy that the teacher is not authorized and is not responsible for diagnosing, first because it is not within his competence, his training and second, mood disorders, such as depression, are delicate and it needs, as expected, a thorough evaluation to obtain the diagnosis. However, for the identification of depressive symptoms, the educator's sensitive look cooperates a lot in the clinical evaluation (Hemery, 2008).

It is essential that the teacher, pedagogue, the entire teaching class, have knowledge about the psychopathologies that are present in children and young people, knowing when to detect something different, talk to the legal guardians and suggest a psychotherapeutic follow-up (Carmo et al., 2009).

In this way, a qualified and sensitive educator in their eyes can provide the promotion of mental health, as well as acting in the prevention of psychopathologies, for example, in the identification of the symptoms of depression, collaborating in early intervention, enabling positive responses and improving the life of the child and young person, as well as taking part in the recovery and treatment of this student, with affection, empathy, respect, listening, inclusive learning and others (Vieira, Estanislau, Bressan, \& Bordin, 2014).

With this, as the educator and philosopher Cipriano Luckesi states, "the educator will never be definitively ready, formed, since his maturation takes place on a daily basis in theoretical meditation on practice" (Luckesi in Corrêa, 2019).

\section{Final Considerations}

From the results presented, the objective of this study was achieved. Despite this, we can see that there is still little research on childhood depression in the Brazilian context. Therefore, it is extremely important to have further studies on this topic, especially after the pandemic context of COVID-19, with consequences such as social isolation and others.

It is important to spread knowledge about mood disorders, especially depres- 
sion in children and young people. According to the scientific literature, the acceptance of depressed children is recent, compared to diagnoses in adults.

However, we can note the existence of depressive symptoms in children and adolescents, based on evidence from clinical studies, although still little, and in which it interferes and affects several factors, whether biological, psychological and social. The consequences of this, for example, are neurobiological alterations, such as uncontrolled serotonergic, dopaminergic neurotransmitters, disinterest, psychomotor retardation, aggressiveness, somatic pain, sleep, anxiety, phobias, social withdrawal, learning such as concentration difficulties and others.

The understanding of the integral being, that is, being biopsychosocial, broadens the horizons about psychopathologies, realizing that no one is immune. As a result, children and young people living with depression affect their lives too much. According to surveys by the World Health Organization (WHO), the prevalence rate of mental disorders is growing and is worrying, being a public health problem, probably the most disabling disease in the world.

In Brazil, it is still necessary to strengthen the approach to the theme of Health in schools, having as a cross-cutting, covering the entire school curriculum, providing actions that benefit individual and collective health. There is in some countries the integration of health and education sectors. Brazil still has major obstacles to be resolved and one of them is the lack of dialogue between the health and education sectors. In this context, assessment programs about children's mental health and early detection can help prevent the advance of mental disorders, specifically depression and/or mitigating its intensity, when already established.

From this perspective, public projects for the qualification of educators on mental health are remarkable, and may have great chances of effectiveness, in addition to socio-emotional learning actions in schools, bringing family members, the children's parents, closer, thus having positive bonds. Therefore, problems related to mental health require discussions and reflections, especially the articulation of health and education professionals.

It is important to emphasize that the teachers are not responsible for the diagnosis, as it is up to the health professional to assess and investigate the case, but the sensitive, ethical and sensitive pedagogical listening of the teacher is convenient and very relevant, helping to improve the child and the young. There is also agreement in the scientific literature, showing that the family has a fundamental role in the child's biopsychosocial formation, addressing that affection, attention, help, autonomy, in the case of young people, are important aspects for the prevention of disorders, emotional, as well as school can be a conducive environment for health promotion.

Thus, government projects are needed, especially in the public sphere, providing pedagogical actions based on neurosciences, such as the qualification of the teaching staff, in partnership with psychological and medical care, supporting not only the student, but also the family. The use of social media, sharing 
knowledge about childhood depression, as well as more scientific research aimed at this audience is needed. The earlier the detection of depressive symptoms in children and young people, the proper treatment will enable positive responses in the lives of individuals, influencing the rate of serious problems, such as suicide.

\section{Conflicts of Interest}

The authors declare no conflicts of interest regarding the publication of this paper.

\section{References}

Albuquerque, C. (2018). Portugal na vanguarda da promoção da saúde mental de crianças e adolescentes. Acta Paulista de Enfermagem, 31, 3-5. https://doi.org/10.1590/1982-0194201800064

Andriola, W. B., \& Cavalcante, L. R. (1999). Avaliação da depressão infantil em alunos da pré-escola. Psicologia: Reflexão e Crítica, 12, 419-428. https://doi.org/10.1590/S0102-79721999000200011

Argimon, I. I. L., Terrosso, L. B., Barbosa, A.S., \& Lopes, R. M. F. (2013). Intensidade de sintomas depressivos em adolescentes através da escala de depressão de Beck (BDI-II). Boletim-Academia Paulista de Psicologia, 33, 354-372.

Bahls, S. C. (2002). Epidemiology of Depressive Symptoms in Adolescents of a Public School in Curitiba, Brazil. Brazilian Journal of Psychiatry, 24, 63-67. https://doi.org/10.1590/S1516-44462002000200005

Bahls, S.-C. (2004). A depressão em crianças e adolescentes e o seu tratamento. Lemos Editorial.

Bandim. J. M., Sougey, E. B., \& Carvalho, T. F. R. (1995). Depressão em crianças: Características demográficas e sintomatologia. Jornal Brasileiro de Psiquiatria, 44, 27-22.

Baptista, C. A., \& Golfeto, J. H. (2000). Prevalência de depressão em escolares de 7 a 14 anos. Revista de Psiquiatria Clínica, 27, 253-256.

Baptista, M. K., Borges, L., \& Serpa, A. L. O. (2017) Diferenças de Sexo e Idade Relacionadas aos Sintomas Depressivos entre Crianças e Adolescentes Brasileiros. Paidéia (Ribeirão Preto), 27, 290-297. https://doi.org/10.1590/1982-43272768201706

Baptista, M. N. (2009). Inventário de Percepção do Suporte Familiar-IPSF: Manual. Vetor.

Baptista, M. N., Baptista, A. S. D., \& Dias, R. R. (2001). Estrutura e suporte familiar comofatores de risconadepressão de adolescentes. Psicologia: Ciência e Profissão, 21, 52-61. https://doi.org/10.1590/S1414-98932001000200007

Barbosa, G. A., \& Gaião, A. A. (2001). Apontamentos em Psicopatologia infantil. Idéia.

Barrera Jr., M., Sandler, I. N., \& Ramsay, T. B. (1981). Preliminary Development of a Scale of Social Support: Studies on College Students. American Journal of Community Psychology, 9, 435-447. https://doi.org/10.1007/BF00918174

Birtchnell, J. (1988). Depression and Family Relantionships. A Study of Young, Married Women on a London Housing Estate. British Journal of Psychiatry, 153, 758-769. https://doi.org/10.1192/bjp.153.6.758

Bock, A. M. B., Furtado, O., \& Teixeira, M. L. T. (1999). Psicologias: Uma introdução ao estudo da psicologia. Saraiva.

Borges, L., \& Baptista, M. N. (2015). Construção e estudospsicométricos da Bateria de 
Avaliação de Indicadores de DepressãoInfantojuvenil (BAID-IJ). (Tese de doutorado). Universidade São Francisco.

Borges, L., \& Pacheco, J. T. B. (2018). Sintomas depressivos, autorregulação emocional e suporte familiar: Um estudo com crianças e adolescentes. Est. Inter. Psicologia, 9, 132-148. https://doi.org/10.5433/2236-6407.2018v9n3suplp132

Carmo, A. L., Silva, S. P. B., \& Troncoso, A. C. (2009). Depressão Infantil: Uma realidade presente na escola. Nucleus, 6, 338. https://doi.org/10.3738/1982.2278.180

Chartier, G. M., \& Lassen, M. K. (1994). Adolescent Depression: Childrens Depression Inventory Norms, Suicidal Ideation and (Weak) Gender Effects. Adolescence, 29, 859-864.

Cória-Sabini, M. A. (1998). Psicologia do Desenvolvimento. Editora Ática.

Corrêa, C. (2019). Plano de aula: Sentimentos e Emoções. Website Profissão Professor.

Couto, I. S. L., Reis, D. M. L., \& Oliveira, I. R. (2016). Prevalência de sintomas de depressão em estudantes de 11 a 17 anos da rede pública de ensino de Salvador. Revista de Ciências Médicas e Biológicas, 15, 370-374.

Cruvinel, M. (2003). Depressão Infantil, rendimento escolar e estratégias de aprendizagem em alunos do ensino fundamental. Dissertação de Mestrado, Faculdade de Educação. Universidade Estadual de Campinas.

Cruvinel, M., \& Boruchovitch, E. (2003). Depressão Infantil: Uma contribuição para a prática educacional. Psicologia Escolar e Educacional, 7, 77-84. https://doi.org/10.1590/S1413-85572003000100008

Cruvinel, M., \& Boruchovitch, E. (2004). Sintomas depressivos, estratégias de aprendizagem e rendimento escolar de alunos do ensino fundamental. Psicologia em Estudo, 9, 369-378. https://doi.org/10.1590/S1413-73722004000300005

Cruvinel, M., \& Boruchovitch, E. (2008). Sintomas depressivos em crianças: estudos com duas versões do CDI. Psicologia: Ciência e Profissão, 28, 574-585. https://doi.org/10.1590/S1414-98932008000300011

DSM-V. (2014) Manual Diagnóstico e Estatístico de Transtornos Mentais. American Psychiatric Association.

Duailibi, K., \& Silva, A. S. M. (2013). Depressão: Como diagnosticar e tartar. Ed. Moreira Jr.

Erikson, E. H. (1987). Infância e Sociedade (2a ed). Zahar Editores.

Fleming, J. E., Offord, D. R., \& Boyle, M. H. (1989). Prevalence of Childhood and Adolescent Depression in the Community. The British Journal of Psychiatry, 155, 647-654. https://doi.org/10.1192/S0007125000018146

Fonseca, F. M. H., Ferreira, R. A., \& Fonseca, S. G. (2005). Prevalência de sintomas depressivos em escolares. Pediatria, 27, 223-232.

Gerhardt, T., \& Silveira, D. (2009). Métodos de pesquisa. Série Educação a Distância. UFRGS (Universidade Federal do Rio Grande do Sul).

Golfeto, J. H., Oliveira, D. A. B., Baptista, C., \& Bisson, F. (2011). Prevalência da sintomatologia depressiva nas cidades de Ribeirão Preto e região. Pediatria Moderna, 47, 2.

Hallak, L. R. L. (2001). Estimativa da prevalência de sintomas depressivos em escolares da rede pública de Ribeirão Preto. Dissertação de Mestrado, Faculdade de Medicina de Ribeirão Preto da Universidade de São Paulo (USP).

Hemery, J.-J. R. (2008). Depressão infantil. Revista do Professor No. 80.

Kandel, E., Jessell, T., \& Schwartz, J. H. (2014). Princípios de Neurociências. Ed. Artmed.

Kupfer, D. J., \& Regier, D. A. (2014). Manual Diagnóstico e Estatístico de Transtornos 
Mentais (DSM-V) (5Edição). American Psychiatric Association, Ed. Artmed.

Lovisi, G. M., Milanil, I., Caetano, G., Abelha, L., \& Morgado, A. F. (1996). Suporte Social e Distúrbios Psiquiátricos: Em que Base se Alicerça a Associação? Informação Psiquiátrica, 15, 65-68.

Marconi, E. V. N. (2017). Depressão Infantil: Uma Revisão Bibliográfica. Psicologia.PT.

Miller, J. A. (2003). O livro de referência para Depressão Infantil. Ed. M.Books.

Minayo, M. C. S. (2004). O desafio do conhecimento: Pesquisa qualitativa em saúde (8th ed.). Hucitec.

Minuchin, S., \& Fishman, H. C. (1990). Técnicas de Terapia Familiar (Trad. Claudine Kinsch e Maria Efigênia F. R. Maia). Artes Médicas.

Molina, M. R. A. L., Wiener, C. D., Branco, J. C., Jansen, K., Souza, L. D. M, Tomasi, E., Silva, R. A., \& Pinheiro, R. T. (2012). Prevalência de depressão em usuários de unidades de atenção primária. Revista de Psiquiatria Clínica, 39, 194-197. https://doi.org/10.1590/S0101-60832012000600003

Noronha, A. P. P., \& Baptista, M. N. (2016). Escala de Avaliação da Autorregulação Emocional-EARE. (Relatóriotécniconãopublicado). Universidade São Francisco.

Oliveira, C. B. E. D., \& Marinho-Araújo, C. M. (2010). A relação família-escola: Intersecções e desafios. Estudos de Psicologia, 27, 99-108. https://doi.org/10.1590/S0103-166X2010000100012

Papp, P. (1992). O Processo de Mudança: Uma Abordagem Prática ŕ Terapia Sistęmica da Família. Artes Médicas.

Parker, G., Tupling, H., \& Brown, L. B. (1979). A Parental Bonding Instrument. British Journal of Medical Psychology, 52, 1-10. https://doi.org/10.1111/j.2044-8341.1979.tb02487.x

Pavoski, G. T. T., Toni, C. G. S., Batista, A. P., \& Ignachewski, C. L. (2017). Capacidades e dificuldades socioemocionais de crianças antes e após a participação no método Friends. Revista Psicologia e Saúde, 11, 111-123.

Petzold, M. (1996). The Psychological Definitions of the Family. Em Cusinato (Ed.), Research on Family Resources and Needs across the World (pp. 25-44). Edizioni Universitarie di Lettere Economia Diritto.

Procidano, M. E., \& Heller, K. (1983). Measures of Perceived Social Support from Friends and from Family: Three Validations Studies. American Journal of Community Psychology, 11, 1-24. https://doi.org/10.1007/BF00898416

Rocha, T. H. R., Ribeiro, J. E. C., Pereira, G. A., Aveiro, C. C., \& Silva, L. C. A. (2006). Sintomas depressivos em adolescentes de um colégio particular. Psico-USF, 11, 95-102. https://doi.org/10.1590/S1413-82712006000100011

Stern, C., Jordan, Z., \& McArthur, A. (2014). Developing the Review Question and Inclusion Criteria, the First Steps in Conducting a Systematic Review. American Journal of Nursing, 114, 53-56. https://doi.org/10.1097/01.NAJ.0000445689.67800.86

Teixeira, L. (2018). 66\% dos professores já precisaram se afastar por problemas de saúde. Revista Nova Escola.

Thiengo, D. L., Cavalcante, M. T., \& Lorisi, G. M. (2014). Prevalência de transtornos mentais entre crianças e adolescentes e fatores associados: Uma revisão sistemática. Jornal Brasileiro de Psiquiatria, 63, 360-372. https://doi.org/10.1590/0047-2085000000046

Vieira, M. A., Estanislau, G. M., Bressan, R.A., \& Bordin, I. A. (2014). Saúde Mental na Escola. Artmed. 
White, J. (1989). Depression. In The Troubled Adolescent (pp. 111-143). Pergamon General Psychology Series.

Windle, M. (1991). The Difficult Temperament in Adolescence: Associations with Substance Use, Family Support, and Problem Behaviors. Journal of Clinical Psychology, 47, 310-315.

https://doi.org/10.1002/1097-4679(199103)47:2\%3C310::AID-JCLP2270470219\%3E3.0. CO;2-U

World Health Organization (2002). Relatório Mundial da Saúde. Saúde Mental: Nova concepção, nova esperança ( $1^{\circ}$ Edição). Ministério da Saúde. 